\title{
A museologia e a construção de sua dimensão social: olhares e caminhos \\ Mario Chagas ${ }^{1}$, Judite Primo ${ }^{2}$, Paula Assunção ${ }^{3}$, Claudia Storino ${ }^{4}$
}

\begin{abstract}
Resumo
Olhar para a museologia, de modo especial, para a denominada museologia social ou sociomuseologia, conversando com ideias e noções que podem ser consideradas óbvias, mas que, talvez, examinadas por outro ângulo, tenham algo de novo a oferecer, faz parte dos objetivos do presente texto. Além disso, é pertinente perguntar: o óbvio é óbvio para quem? Não raro, aquilo que parece óbvio para determinados grupos de especialistas, pode não ser óbvio para uma grande maioria de pessoas. É neste sentido que peregrinando pela obviedade, afirma-se que a museologia social ou sociomuseologia não surgiu do nada e também não é o resultado de intelectuais iluminados que retiraram de si mesmos, de suas essências a luz museal ou museística que haveria de iluminar o mundo; ao contrário, surgiu de amplos debates e embates, de um acúmulo de tensões, críticas, enfrentamentos, vivências, reflexões e práticas que impactaram a museologia e os museus que do século XIX,
\end{abstract}

1 Poeta. Diretor do Museu da Republica, professor da Unirio, pmariosc@gmail.com

${ }^{2}$ Diretora do Departamento de Museologia da ULHT

Judite.primo@ulusofona.pt

${ }^{3}$ Professora na Reinwardt Academy, em Amsterdã, Holanda.

pasadam@gmail.com

${ }^{4}$ Diretora do Centro Cultural Sítio Roberto Burle Marx, Unidade Especial do IPHAN.

cmstorino@gmail.com 
projetaram-se no século $X X$, sem que seus paradigmas tivessem sido submetidos a uma análise crítica.

Em outros termos: a museologia social ou sociomuseologia não é o resultado de uma construção teórica que quer, a todo custo, de cima para baixo, enquadrar os museus e as diferentes formas de pensar e praticar a museologia aos seus ditames técnicos, científicos, artísticos e filosóficos; ao contrário, trata-se de uma construção que resulta de um contexto histórico específico, que não tem e não quer ter um caráter normativo e que apresenta respostas singulares para problemas também singulares e que, sobretudo, assume explicitamente compromissos políticos e poéticos.

Palavras-chave: Museologia; museologia social; sociomuseologia; educação; memória; função social do museu.

\section{Abstract \\ Museology and the construction of its social dimension: perspectives and paths}

To regard museology, in a special way, the so-called social museology or sociomuseology, conversing with ideas and notions that might be considered obvious, but which, perhaps, if examined by another angle, have something new to offer, is part of this essay's objectives. Besides, it is relevant to ask: to whom is the obvious, obvious? Frequently, that which seems obvious to certain groups of specialists may not be obvious to a great majority of people. It's in this sense that, wandering through obviousness, we may affirm that Social Museology or Sociomuseology did not arise out of nowhere and neither is it the result of illuminated intellectuals who brought out of themselves, of their essences, the museal or museistic light that was to illuminate the world; on the contrary, it emerged from wide-ranging discussions and clashes, of built-up of tensions, criticism, confrontations, experiences, reflections and practices that impacted museology and museums which had advanced from the $19^{\text {th }}$ century into the $20^{\text {th }}$ without submitting their paradigms to a critical analysis.

In other words: social museology, or sociomuseology, is not the result of a theoretical construction that wants, at any cost, from the top 
down, to frame museums and different forms of thinking and practicing museology to its technical, scientific, artistic and philosophical dictates; on the contrary, it is a construction resulting from a specific historical context, that doesn't have, and doesn't want to have, a normative character; that presents singular answers to also singular problems and that, above all, explicitly assumes political and poetical commitments.

Keywords: Museology; social museology; sociomuseology; education; memory; social role of museums.

\section{Museologia social: alguns antecedentes}

Paulo Freire, o "educador das obviedades", ${ }^{5}$, como ele próprio gostava de se definir, sugeriu que é importante peregrinar pelo óbvio e buscar em seu coração o vestígio do novo e das novidades. Seguindo suas sugestões os autores do presente texto querem olhar para a museologia e, de modo especial, para a denominada museologia social ou sociomuseologia conversando com algumas ideias e noções que podem ser consideradas óbvias, mas que, talvez, olhadas por outro ângulo, tenham algo de novo a oferecer. Além disso, é pertinente perguntar: o óbvio é óbvio para quem? Não raro, aquilo que parece óbvio para determinados grupos de especialistas, pode não ser óbvio para uma grande maioria de pessoas. É neste sentido que peregrinando pela obviedade, quer-se afirmar que a museologia social ou sociomuseologia não surgiu do nada e também não é o resultado de intelectuais iluminados que retiraram de si mesmos, de suas essências a luz museal ou museística que haveria de iluminar o mundo; ao contrário, surgiu de amplos debates e embates, de um acúmulo de tensões, críticas, enfrentamentos, vivências, reflexões e práticas que

\footnotetext{
${ }^{5}$ Ver o artigo "O obvio na relação pedagógica", de Suzana Schwartz e Lourdes Maria Bragagnolo Frison, disponível em: http://revistaseletronicas.pucrs.br/ojs/index.php/faced/article/viewFile/5781/4 202.
} 
impactaram a museologia e os museus que do século XIX, projetaram-se no século $X X$, sem que seus paradigmas tivessem sido submetidos a uma análise crítica.

Em outros termos: a museologia social ou sociomuseologia não é o resultado de uma construção teórica que quer, a todo custo, de cima para baixo, enquadrar os museus e as diferentes formas de pensar e praticar a museologia aos seus ditames técnicos, científicos, artísticos e filosóficos; ao contrário, trata-se de uma construção que resulta de um contexto histórico específico, que não tem e não quer ter um caráter normativo e que apresenta respostas singulares para problemas também singulares e que, sobretudo, assume explicitamente compromissos políticos e poéticos.

Por esse caminho, compreende-se que a museologia social se constituiu e se constitui "in mundo", ou seja, na relação direta com a sociedade, com as demandas e questionamentos de segmentos sociais específicos.

A partir dos anos de 1960 e 1970 comportamentos, tradições estabelecidas, práticas religiosas oficiais, instituições consagradas como escolas, museus e teatros passaram a ser fortemente criticadas por movimentos sociais, intelectuais e setores da juventude. Estas críticas acompanhadas de ações e gestos concretos foram cruciais para que tradições fossem rompidas, novos modos comportamentais fossem acionados, novas formas poéticas, filosóficas e religiosas entrassem em cena e novas possibilidades de pensar e praticar museus e museologias fossem também colocadas em movimento. Aqui está, em certa medida, a origem de algumas reflexões e práticas do que se convencionou denominar de nova museologia.

A esse respeito Peter Van Mensch identifica duas "revoluções" na história dos museus, uma ocorrida entre os anos de 1880 e 1920 e outra no período de 1960 e 1980. Depois de discorrer sobre a primeira, Van Mensch indica que, além da sinergia das discussões sobre os níveis prático, teórico e crítico 
dos museus, uma das principais características da segunda é o desejo de tratar e afirmar "os museus como instituições sociais com agendas políticas". "Em ambos os períodos - diz ele - a ruptura por meio de um novo pensamento foi acompanhada de uma nova 'retórica'. A nova retórica da segunda revolução do museu tem sido denominada de 'Nova Museologia' ${ }^{6 \prime}$. Convém sublinhar que aquilo que Peter Van Mensch denomina de "nova retórica" não se esgota num possível caráter simbólico e discursivo, ao contrário, tem impactos concretos e transformadores em muitos grupos sociais, em muitas iniciativas museais.

No entanto, antes da nova museologia e da museologia social ganharem a cor e a configuração que vieram a ter, algumas experiências nacionais e internacionais foram decisivas. No caso brasileiro, é importante citar três referências: o Museu de Imagens do Inconsciente, o Museu do Índio e o Museu de Arte Negra. Cada um deles foi, ao seu modo, inovador e esteve vinculado a um projeto específico e a uma liderança singular.

O Museu de Imagens do Inconsciente vinculado ao trabalho de Nise da Silveira ${ }^{7}$, conhecida como psiquiatra rebelde, é um museu revolucionário. Criado em 1952, no interior de uma instituição manicomial conhecida como Centro Psiquiátrico Nacional Pedro II, o museu nasceu da insubordinação de Nise da Silveira e de sua rejeição às práticas médicas de eletrochoque, insulinoterapia e lobotomia. Como uma forma de punição de sua rebeldia Nise foi deslocada para o trabalho de terapia ocupacional, atividade menosprezada pelos médicos, e foi desse lugar do desprezo e do menosprezo que nasceu um museu que passou a apresentar a potência de vida, a potência poética e

\footnotetext{
${ }^{6}$ Ver páginas 75-76 do livro "Introducción a la nueva museología", de Luis Alonso Fernandez, publicado por Alianza Editorial, em 1999, Madrid.

${ }^{7}$ Nise da Silveira (Maceió, 15 de fevereiro de 1906 - Rio de Janeiro, 30 de outubro de 1999) dedicou-se à psiquiatria e manifestou-se radicalmente contra às formas agressivas de tratamento psíquico.
} 
política dos loucos, dos esquizofrênicos, dos doentes mentais, dos hóspedes do hospital psiquiátrico. Do ponto de vista prático, teórico e crítico é importante reconhecer que o Museu de Imagens do Inconsciente não lidava com um acervo herdado, mas com um acervo que estava em construção e que se fazia e se refazia permanentemente; além disso, ele não estava instalado num edifício palaciano e de caráter extraordinário, mas num prédio construído para ser hospital; por fim, ele não estava orientado para o grande público, mas para os eventuais familiares dos hóspedes, a comunidade hospitalar e seus apoiadores, incluindo estudantes, professores, artistas, críticos de arte e intelectuais de diferentes matizes ideológicas.

O Museu do Índio vinculado ao trabalho de Darcy Ribeiro ${ }^{8}$ assumiu, desde sua fundação em 1953, a luta contra o preconceito. Darcy Ribeiro teve uma atuação especial, rebelde e diferenciada no que se refere aos museus, à educação e à política. A rigor, foi um demiurgo de museus, escolas e universidades. O Museu do Índio, ainda que não seja o único, é o seu projeto museal mais notável. Do ponto de vista prático, teórico e crítico é importante reconhecer que o Museu do Índio foi um dos primeiros museus brasileiros a abraçar explicitamente uma "causa", qual seja, a luta contra o preconceito em relação aos povos indígenas. Em termos museológicos realizou-se ali a decisão de não apresentar os povos indígenas como fósseis, e sim como povos contemporâneos; foi também ali onde se construiu um discurso que, mesmo tendo características românticas, afirmava o desejo de beleza de determinados povos indígenas; foi ainda ali que se criou um Curso pioneiro de pós-graduação (ao nível de especialização) em antropologia. O Museu serviu de inspiração para diversos outros projetos e mesmo hoje continua

\footnotetext{
${ }^{8}$ Darcy Ribeiro (Montes Claros, 26 de outubro de 1922 - Brasília, 17 de fevereiro de 1997) foi antropólogo, educador, escritor e político. Trabalhou de modo radical a favor dos povos indígenas e da educação pública.
} 
tendo relativa importância na defesa dos direitos de alguns povos indígenas, especialmente a partir de seus acervos arquivístico e museológico que podem, em certos casos, funcionar como documentos comprobatórios.

O Museu de Arte Negra vinculado à atuação intelectual, política e militante de Abdias do Nascimento ${ }^{9}$ é um projeto pouco conhecido e que, por isso mesmo, merece ser estudado. Em 1955, Abdias acolheu a sugestão de Guerreiro Ramos e realizou um concurso de artes plásticas sobre o tema "Cristo Negro", do qual participaram mais de cem artistas. $O$ trabalho vitorioso foi o Cristo na coluna, de Djanira, evocando um "negro no pelourinho escravocrata". Desse concurso resultou a idéia de se criar o Museu de Arte Negra, cuja primeira exposição pública ocorreu em maio de 1968, no Museu da Imagem e do Som. Oito anos mais tarde, Abdias refletiu sobre esse projeto inovador, dizendo:

O Museu de Arte Negra sofre de uma ambiguidade profunda. É sobre o negro, mas inclui trabalhos de artistas brancos, também. Mais grave é a própria natureza do museu, um troço estático só conhecido e visitado por gente da classe média para cima, só apreciado pelos "entendidos". Para preencher o seu sentido, o museu tinha de ser móvel, subir nos morros, viajar pelo interior do país. Recolher o material criado, exibi-lo para ser discutido, difundido, enriquecido com outras experiências. Valorizar a arte afro-brasileira tendo em vista o povo afro-brasileiro: nós não tivemos condições para este

\footnotetext{
${ }^{9}$ Abdias Nascimento (Franca, 14 de março de 1914 - Rio de Janeiro, 24 de maio de 2011) foi poeta, ator, dramaturgo, artista plástico, político e ativista dos direitos humanos das populações negras. Fundou o Teatro Experimental do Negro (TEN), o Museu da Arte Negra (MAN) e o Instituto de Pesquisas e Estudos Afro-Brasileiros (IPEAFRO).
} 
tipo de revolução estética e cultural (NASCIMENTO, 1976: 42-43).

As experiências do Museu de Imagens do Inconsciente e do Museu de Arte Negra evocadas neste estudo, ao lado das vividas pelo Museu do Índio, cumprem um papel especial: evidenciar que o campo dos museus no Brasil continua aberto para diferentes experiências de imaginação criativa e de(s)colonial, não alinhadas com os museus clássicos tradicionais. Essas experiências também servem para recordar que o desafio de lavrar esse campo continua renovado, sobretudo num país onde os processos de exclusão social também se renovam ${ }^{10}$.

Para além dessas três experiências brasileiras é importante lembrar, por exemplo, aquelas que foram citadas no livro "Os Museus no Mundo", publicado em 1979, na Espanha, na Suíça e no Brasil, no âmbito da coleção Grandes Temas da Biblioteca Salvat.

Nesse livro popular, está incluída uma extraordinária entrevista com Hugues de Varine. Nessa entrevista estão indicadas, entre outras coisas, algumas experiências inovadoras. Entre essas experiências Varine destacou o caso francês em que estava diretamente envolvido: um museu que compreendia 150 mil habitantes, distribuídos em 22 comunas, em 22 vilas e cidades; na sequência destacou a rede de museus comunitários e escolares do México e deu ênfase ao Museu Nacional de Niamey, no Níger:

"Desde 1958 - diz ele - (...) existe ali [em Niamey] um museu muito original, feito por um catalão exilado, sem qualificação acadêmica ou universitária, sem especialização, e que

${ }^{10}$ Ver o livro A Imaginação Museal: museu, memória e poder em Gustavo Barroso, Gilberto Freyre e Darcy Ribeiro, de Mario Chagas, publicado em 2009, pelo Instituto Brasileiro de Museus (Ibram). 
simplesmente se guiou pelas necessidades e problemas do país. Criou assim um Instituto de Folclore e Arqueologia que nuns 20 hectares de superfície abrange um conjunto grande de problemas: museu etnológico ao ar livre, jardim para crianças, jardim zoológico e botânico, lugar para espairecer e passear, para os desfiles de moda africana e europeia, e centro para promoção de um artesanato de qualidade que fabrica objetos úteis; constitui, afinal, a maior escola de alfabetização e, quando é o caso, um centro de difusão de programas musicais." (VARINE, 1979, p.73)

O referido livro discutiu temas como: "Museu e sociedade", "Novas experiências", "Dimensão pedagógica do museu", "A projeção social do museu", "Tentativas de ruptura formal", "As relações público-museu", "Análise de um modelo de gestão: o Museu Antropológico do México" e o "Alcance das inovações".

O Museu Nacional de Antropologia do México que tinha em Mario Vázquez Rubalcava a sua âncora conceitual e museográfica foi apresentado como um exemplo inovador em termos de gestão e projetos criativos. Mario Vázquez teve um papel fundamental na renovação da museologia no México e no mundo. Segundo Hugues de Varine, durante a IX Conferência Geral do Icom, realizada en Paris, Dijon e Grenoble, o beninense Stanislas Adotévi e o mexicano Mario Vásquez proclamavam abertamente: a "revolução do museu será radical, ou o museu desaparecerá"11.

Ao tratar do tema "Tentativas de ruptura formal" o livro apresenta um relato sobre o Museu de Anacostia, pertencente a Smithisonian, situado nos arredores de Washington e que

\footnotetext{
${ }^{11}$ Ver o texto O Ecomuseu, de Hugues de Varine, publicado na revista Ciencias \& Letras, Porto Alegre, n. 27, p. 61-101, Janeiro/Junho. 2000.
} 
desenvolveu experiências memoráveis, entre as quais encontrase a famosa exposição sobre o Rato. Este museu e suas experiências pioneiras durante a gestão de John Kinard transformaram-se em referência para a nova museologia e em seguida para a museologia social.

Em Portugal, na Espanha, na França, no México, no Canadá, nos Estados Unidos da América, na Argentina, na Colômbia, no Chile, no Brasil e um pouco por todo o mundo as experiências de uma outra museologia estavam se valorizando e disseminando e o livro em questão era um bom documento de referência, sobretudo por seu caráter popular.

Ao lado dessas experiências, desenvolveram-se também novas abordagens teóricas, especialmente fora do núcleo duro da Europa. ${ }^{12}$.

\section{A nova museologia e a pedra no meio do caminho}

Em 1984, realizou-se em Quebec, no Canadá, uma reunião internacional que produziria um documento muito simples, objetivo e radical, que ficaria internacionalmente conhecido como a Declaração de Quebec e que daria origem ao Movimento Internacional para uma Nova Museologia (MINOM) que, a rigor, contribuiu para a produção de um divisor de águas nos campos museal e museológico. Em pouco tempo, especialmente nas décadas de 1980 e 1990, o temário e os problemas elencados pela denominada nova museologia espalharam-se pelo mundo ${ }^{13}$. $\mathrm{E}$, do ponto de vista do MINOM, o ICOM esteve frequentemente no papel do obstáculo e raramente atuou como alavanca, ainda que em alguns momentos isso tenha acontecido e que nos últimos tempos essa situação tenha passado por sensíveis câmbios.

\footnotetext{
${ }^{12}$ Ver Cadernos do CEOM, ano 27, n.41, Dez. 2014. Dossiê: Museologia Social. p.9-22.

13 Idem
} 
O período compreendido entre 1984 e 1994 foi marcado por uma forte disputa entre os apoiadores da nova museologia e os defensores de uma museologia tradicional, clássica ou ortodoxa, assim considerada, evidentemente, a partir do ponto de vista dos seus opositores ${ }^{14}$.

De acordo com Chagas e Gouveia: "Arrefecido o calor da batalha dos primeiros anos, foi se estabelecendo gradualmente uma tendência de indistinção, de indiferenciação. Mesmo instituições conservadoras e clássicas passaram a incorporar o jargão e em certos casos determinadas práticas e metodologias da denominada nova museologia, o mesmo aconteceu com determinados profissionais, sem que isso representasse a adesão aos compromissos éticos e políticos que embasavam a nova museologia. A expressão virou moda e perdeu potência. E alguns daqueles que passaram a falar em nome da nova museologia passaram também a querer estabelecer regras definidoras do que é um novo museu, do que é um ecomuseu, do que é um museu comunitário, do que é um museu de território e com isso tentaram enquadrar a nova museologia no âmbito das práticas e procedimentos da museologia normativa" ${ }^{15}$.

A assim chamada nova museologia, desde os anos de 1980 abrigava diferentes denominações: museologia popular, museologia ativa, ecomuseologia, museologia comunitária, museologia popular, museologia de ruptura, museologia crítica, museologia dialógica e outras. A perda de potência da expressão nova museologia foi decisiva para o fortalecimento e a ascensão, especialmente após os anos de 1990, da denominada museologia social ou sociomuseologia, bem como da museologia crítica ${ }^{16}$.

Há nestas múltiplas designações pelo menos um aspecto altamente positivo, qual seja a evidência de uma potência 
criativa, de uma capacidade de invenção e reinvenção de experiências e iniciativas. A multiplicidade de designações evidencia também a disposição para driblar e resistir às tentativas de normatização, estandardização e controle perpetradas por determinados setores culturais e acadêmicos. Essas museologias indisciplinadas, impuras, in-mundas, crescem de mãos dadas com a vida, elaboram permanentemente seus saberes e fazeres à luz das transformações sociais que vivenciam como protagonistas, por isso mesmo é no fluxo, no refluxo e no contra-fluxo que se nomeiam e renomeiam, se inventam e reinventam, permanentemente ${ }^{17}$.

Tinha uma pedra no meio do caminho da museologia. No meio do caminho da museologia tinha uma pedra. Terá um caminho no meio da pedra? No presente texto compreende-se que as expressões museologia, nova museologia, museologia social e sociomuseologia não têm valor em si, e, ainda mais, por si não podem nada, tudo depende do que se quer e do que efetivamente se consegue fazer com elas. É nas relações sociais e políticas, nas relações objetivas e subjetivas que estas expressões ganham ou perdem sentido.

\section{Museologia social como campo de disputa ou a quem pertence o social da museologia?}

Memórias, patrimônios e museus são bons para pensar, sentir e agir; para lidar com eles é importante quebrar a coluna vertebral da ingenuidade. Museus, memórias e patrimônios são territórios inseguros, não são propícios para quem tem medo de se afogar ou despencar no abismo.

Memórias, patrimônios e museus são campos de luta, conflito, litígio. Nestes campos disputa-se tudo. Disputa-se o passado, o presente e o futuro; o lugar, o espaço e o território; a amizade, o amor e a atenção; a liberdade, a criatividade e o

17 Idem 
discurso; disputa-se o substantivo, mas disputa-se também, com especial interesse, o adjetivo.

A quem pertence o novo, a quem pertence o social da museologia? Por mais singela que a pergunta possa parecer, ela tem a capacidade de deslocar o pensamento do lugar comum, da zona de conforto.

Desde o momento em que o adjetivo novo foi acoplado ao termo museologia e especialmente utilizado para designar o Movimento Internacional para uma Nova Museologia, observa-se uma disputa, cada vez mais intensa e acirrada, sobre o que é e o que não é a nova museologia, sobre o que é e o que não é o novo museu. Neste caso, a disputa se deu em relação a positividades, à afirmação discursiva de valores compreendidos como novos. A linha do tempo denominada "Momentos Chaves da Nova Museologia", criada por Luis Alonso Fernández, ainda que incompleta, é uma boa evidência das disputas mencionadas. ${ }^{18}$

Desde o momento em que o adjetivo social foi vinculado ao termo museologia, observa-se também uma disputa. Muitas vozes no campo da museologia passaram a disputar o adjetivo social e algumas passaram a repetir o bordão: "a museologia social não existe, toda museologia é social". O que está em jogo, evidentemente, não é a museologia, mas o social. Daí a questão: a quem pertence o social da museologia? No caso da muselogia social ou sociomuseologia, a disputa se concentrou numa negatividade, ou melhor, na negação da possibilidade do adjetivo social indicar uma diferenciação. Mas quem quer negar e anular a potência do adjetivo social? Que interesses alimentam aqueles que querem despotencializar o social? Os movimentos sociais desde os anos de 1960 enfrentam esta mesma questão.

Uma resposta simples seria dizer que o social da museologia não pertence a ninguém, logo pertence a todos. Essa resposta é

\footnotetext{
${ }^{18}$ Ver páginas 79-81 do livro "Introducción a la nueva museología", de Luis Alonso Fernandez, publicado por Alianza Editorial, em 1999, Madrid.
} 
simples, mas é falsa. O social da museologia continua em disputa. Elevar o pertencer a uma totalidade e reduzir o não pertencer a uma nulidade não contribui para elucidar a questão. Ela exige atenção crítica e diferenciação. A questão permanece: a quem pertence o social da museologia? Seria possível perguntar: o que compreendem como social aqueles que afirmam que toda museologia é social? Por mais interesse que esta pergunta desperte, a original permanece.

O desafio de trabalhar o social na museologia está presente em muitos documentos do Movimento Internacional para uma Nova Museologia (MINOM) e do Conselho Internacional de Museus (ICOM). A questão de fundo não são os documentos produzidos nos encontros, simpósios, seminários, congressos e conferências nacionais e internacionais; esses documentos são apenas documentos e nada mais. A questão é saber que profissionais, professores, pesquisadores, estudantes, artistas, agentes comunitários, moradores de comunidades, apoiadores e instituições nacionais e internacionais assumem o compromisso de trabalhar e trabalham com e a favor de uma museologia de caráter social e participativo. Quem efetivamente está disposto a fazer museologia com e não museologia para? Quem está efetivamente disposto a admitir, dialogar e apoiar a museologia que já não se faz nem com, nem para, mas, como diz Vladimir Sybilla, "a partir de", sem pedir autorização e sem dar satisfação?

A crítica mais sofisticada dirigida à museologia social denuncia o seu caráter político e ideológico. Curiosamente, esta crítica talvez tenha um caráter de elogio. Não há dúvidas: a museologia social tem um acento político, forte e explícito. Esta crítica ingênua ou não mobiliza outra questão: existe ou existirá uma museologia, seja ela qual for, livre de componentes políticos e ideológicos?

As críticas dirigidas à museologia social são todas, sem exceção, de caráter político e ideológico. Não se trata da análise de procedimentos metodológicos referentes à investigação, 
formas de participação, comunicação, documentação e conservação. As críticas até hoje apresentadas são frágeis e não ultrapassam as barreiras ideológicas.

Paira no ar uma questão: haverá diferença ou distinção entre sociomuseologia e museologia social? Para todos os efeitos, o presente texto considera a museologia social e a sociomuseologia como sinônimos. Uma possível diferença, ainda não investigada, talvez esteja nas ênfases, nos pontos de partida, nos diferentes pontos de fuga adotados na Europa e na América Latina. Não faz parte da vontade dos autores deste texto, pelo menos neste momento, realizar esta investigação. Mas, ainda assim, é importante registrar que o desejo de atribuir à sociomuseologia uma dimensão teórica e à museologia social uma perspectiva prática tende a reproduzir um discurso colonialista.

Como indicam Chagas e Gouveia; "O que dá sentido à museologia social não é o fato dela existir em sociedade, mas sim, os compromissos sociais que assume e com os quais se vincula. Toda museologia e todo museu existem em sociedade ou numa determinada sociedade, mas quando falamos em museu social e museologia social, estamos nos referindo a compromissos éticos, especialmente no que se refere às suas dimensões científicas, políticas e poéticas; estamos afirmando (...) a diferença entre uma museologia de ancoragem fascista ou nazista e uma museologia de perspectiva libertária; estamos reconhecendo que durante muito tempo, pelo menos desde a primeira metade do século XIX até a primeira metade do século $X X$, predominou no mundo ocidental uma prática de memória, patrimônio e museu inteiramente comprometida com a defesa dos valores das aristocracias, das oligarquias, das classes e religiões dominadoras.

A museologia social, na perspectiva aqui apresentada, está comprometida com a redução das injustiças e desigualdades sociais; com o combate aos preconceitos; com a melhoria da qualidade de vida; com o fortalecimento da dignidade e da 
coesão social; com a utilização do poder da memória, do patrimônio e do museu a favor das comunidades populares, dos povos indígenas e quilombolas, dos movimentos sociais, incluindo aí, o movimento LGBT, o MST e outros. Seria possível dizer que toda museologia é social, se toda museologia, sem distinção, estivesse comprometida do ponto de vista teórico e prático com as questões aqui apresentadas" ${ }^{19}$.

Olhando por outro ângulo, ainda que em diálogo com a museologia social, Pierre Mayrand lançou em 2007, o Manifesto da Altermuseologia, no qual afirma:

"Hoje, o rolo compressor da globalização obriga mais uma vez o museólogo a juntar a sua energia ao apelo das populações e organizações dedicadas à transformação do quadro museal num Fórum-Ágora-Cidadão, e obriga-o também a se colocar no campo do altermundismo com uma posição didática, dialética, capaz, pelas energias vitais que gera, de fazer progredir o diálogo entre os povos." 20

A museologia social no Brasil continua desenvolvendo-se em ritmo intenso e já agora às margens do poder público e sem pedir permissão para existir, ainda que a obrigação e a responsabilidade do poder público em relação a esses e outros temas não deva ser diminuída. A Rede Cearense de Museus Comunitários, a Rede dos Pontos de Memória e Iniciativas Comunitárias em Memória e Museologia Social do Rio Grande do Sul, a Rede LGBT de Memória e Museologia Social, a Rede São Paulo de Memória e Museologia Social e a Rede de Museologia Social do Rio de Janeiro estão em plena atuação.

\footnotetext{
19 Idem

20 Manifeste L'Altermuséologie lançado por Pirre Mayrand, em Setúbal (Portugal), em 27 de outubro

de 2007. Nesse manifesto, o autor propõe uma Altermuseologia, "um gesto de cooperação, de

resistência, de libertação e solidariedade com o Fórum Social Mundial".
} 


\section{Museologia Social: práticas e experiências diretas}

A seguir são apresentadas cinco experiências desenvolvidas no Brasil, no Estado do Rio de Janeiro, em diálogo com as reflexões, práticas e críticas da museologia social. Por um lado, é importante dizer que a apresentação dessas experiências não tem nenhum caráter exemplar, no máximo elas devem ser consideradas como inspirações; por outro lado, convém registrar que o ponto de partida para a citação destas experiências são as relações diretas de alguns autores com estes processos:

\section{Museu da Maré}

Lançado em maio de 2006, no âmbito do Programa Pontos de Cultura $^{21}$, é o primeiro museu instalado em uma favela da cidade do Rio de Janeiro e administrado pelos próprios moradores e ex-moradores da favela.

O conjunto de favelas da Maré situa-se na Zona Norte da cidade do Rio de Janeiro. Ali vivem mais de 130 mil pessoas, ocupando uma extensão de 800 mil metros quadrados, distribuídas em 16 favelas ou comunidades que guardam entre si semelhanças e diferenças, pluralidades e singularidades históricas, geográficas, culturais, arquitetônicas, musicais e mais. Seu projeto é inovador do ponto de vista histórico, antropológico, educacional, museológico e museográfico e tem servido de inspiração para outras iniciativas de memória e museologia social no país.

No Museu da Maré22 há uma forte articulação entre diferentes gerações. Muitos jovens participam do cotidiano do Museu que está dividido em 12 tempos não cronológicos, mas

\footnotetext{
${ }^{21}$ Para maiores informações recomenda-se o endereço http://www.cultura.gov.br/culturaviva/ponto-de-cultura/apresentacao\#maincontent (última consulta 13 de novembro de 2016).

${ }^{22}$ Para maiores informações recomenda-se o endereço: https://www.facebook.com/museudamare/?fref=ts (última consulta 13 de novembro de 2016).
} 
temáticos. O surgimento do Museu, há dez anos, sacudiu o campo museológico brasileiro, reverberou no plano internacional $^{23}$ e provocou no meio acadêmico entusiasmo, desconforto, polêmica e muitos debates.

\section{Museu Vivo de São Bento}

Lançado em abril de 2007, no município de Duque de Caxias, na baixada fluminense do Estado do Rio de Janeiro, o Museu Vivo de São Bento é uma experiência inovadora. Trata-se de um museu de percurso, também reconhecido como museu de território e ecomuseu, cujo projeto resultou do acúmulo de reflexões e experiências desenvolvidas por um coletivo de professores com atuação na rede estadual e municipal de ensino e no Sindicato Estadual de Profissionais da Educação (SEPE).

O Museu foi institucionalizado no âmbito da Secretaria Municipal de Educação de Duque de Caxias, por intermédio da Lei Municipal no 2224, de 03 de novembro de 2008. Na ocasião, ele foi reconhecido como "um complexo museológico", cujo percurso contava com dez referências ${ }^{24}$, tombadas pela mesma lei como lugares de memória e edificações patrimoniais.

À revelia do próprio Museu a comunidade onde está inserido Ihe atribuiu a função de mediador de conflitos locais. Além disso, o Museu desenvolve projetos de pesquisa, comunicação e preservação do patrimônio material e imaterial. Entre esses projetos incluí-se o Programa Jovens Agentes do Patrimônio,

\footnotetext{
${ }^{23}$ O Museu da Maré teve um papel de destaque no que se refere à decisão para a realização da 23a Conferencia Internacional do ICOM e da 15a Conferência Internacional do MINOM, em 2013, na cidade do Rio de Janeiro.

${ }^{24}$ Ver Lei no 2224, de 7 de novembro de 2008, Prefeitura Municipal de Duque de Caxias, disponível em http://smeduquedecaxias.rj.gov.br. (última consulta: 11 de novembro de 2016).
} 
criado em 2009 e coordenado por professoras vinculadas ao Museu ${ }^{25}$.

\section{Museu de Favela -MUF}

Fundado em 2008 por moradores das favelas Pavão, Pavãozinho e Cantagalo o MUF $^{26}$ é uma organização nãogovernamental, de caráter comunitário, concebido como um museu de território, ancorado na memória social e no patrimônio natural e cultural, tangível e intangível.

Os 20 mil moradores da comunidade, incluindo os seus modos de vida, suas narrativas, suas criações artísticas, seus saberes e fazeres, bem como, o território de 12 hectares, localizado nas encostas do Maciço do Cantagalo, entre os bairros de Ipanema, Copacabana e Lagoa, na zona sul da cidade do Rio de Janeiro, constituem o lócus privilegiado do Museu.

O MUF é singular e trabalha com um patrimônio natural que contém trechos da Mata Atlântica e uma Bacia Visual com panoramas exuberantes; além disso tem atuado numa relação próxima com o turismo. Os seus projetos "Despertar de Almas e Sonhos", "Percurso das Casas Tela", "Ecotrilha", "Mulheres Guerreiras", "Velhos Ilustres", "Afrobetizar", "Brinquedoteca" e "Revista LGBT de Memória e Museologia Social" merecem atenção.

\section{Ecomuseu Nega Vilma}

Lançado em janeiro de 2011, está localizado no alto da comunidade Santa Marta, no terreno onde existiu o barraco (a casa) da Nega Vilma que nasceu em 1943 e faleceu em 2006. Filha da dona Geralda, Nega Vilma foi uma figura marcante na

\footnotetext{
${ }^{25}$ Para maiores informações recomenda-se o endereço: http://www.museuvivodosaobento.com.br/ (última consulta: 11 de novembro de 2016) ${ }^{26}$ Ver o endereço http://www.museudefavela.org ..
} 
comunidade do Santa Marta por sua liderança, por sua atuação como mãe de leite e por ajudar as pessoas do morro e do asfalto com práticas de medicina popular, incluindo banhos de ervas ${ }^{27}$.

O Ecomuseu Nega Vilma está voltado para a realização de atividades ecológicas e artístico-culturais, tais como oficinas de música, artes visuais, teatro, fotografia, exposições, palestras e cursos.

No momento, o Ecomuseu passa por uma fase de refluxo e o seu futuro é incerto. Esse é um ponto importante para pensar os museus sociais e comunitários; esses museus não desejam a eternidade, eles se assumem como efêmeros. Eles são potência e acontecimento, logo a ideia de fracasso neles não tem ressonância.

A esse respeito é importante considerar as reflexões de Hugues de Varine contidas na entrevista ${ }^{28}$ publicada nos Cadernos do CEOM, onde sustenta que o "que se chamava fracasso de um museu comunitário (seja ele denominado ecomuseu ou não) deveria levar outros nomes", uma vez que "o processo vivo de construção de um museu comunitário" pode desembocar em pelo menos três diferentes possibilidades:

a) "o museu desaparece após ter preenchido sua função de mobilização e de dinamização da comunidade. Pode ser substituído por outra coisa: uma ação política, patrimonial, educativa etc., levada por outros meios";

b) "o museu se institucionaliza tornando-se um museu clássico, emanado da comunidade na origem, mas agora estabelecimento de difusão e de ação cultural, a partir de uma coleção e das atividades comuns dos museus";

\footnotetext{
${ }^{27}$ Ver o artigo de Kadão Costa, Dell Delambre e Pollyanna de Azevedo Ferrari https://bell.unochapeco.edu.br/revistas/index.php/rcc/article/view/2612. ${ }^{28}$ Ver a entrevista publicada em http://bell.unochapeco.edu.br/revistas/index.php/rcc/article/view/2605
} 
c) "o museu se transforma em outro processo, igualmente de natureza museológica, mas muito diferente porque adaptado a uma nova geração, a uma comunidade diferente daquela que havia criado o primeiro museu 10 ou 20 anos antes. É um novo avatar, no sentido hindu do termo".

Ainda é possível considerar mais duas hipóteses: a do museu que entra numa espécie de sono, de estado de hibernação e que passa a ter uma atuação sazonal e a do museu que tendo desaparecido, continua habitando o imaginário e a memória social.

\section{Museu das Remoções}

Iniciativa desenvolvida por moradores, apoiadores e amigos da Vila Autódromo, o Museu das Remoções ${ }^{29}$ foi lançado no dia 18 de maio de $2016^{30}$, quando se comemorava o dia internacional de museus, com o tema "Museus e Paisagens Culturais", sugerido pelo Conselho Internacional de Museus (ICOM).

Situada na Barra da Tijuca, no município do Rio de Janeiro, a Vila Autódromo era constituída por pelo menos 600 famílias e estava situada (ironicamente) às margens da Avenida Salvador Allende e da Lagoa de Jacarepaguá. O processo de remoção das famílias da Vila Autódromo foi perverso e muito violento. Em nome do grande capital e de um megaevento de caráter mundial (qual seja, as Olimpíadas), a prefeitura da cidade do Rio de Janeiro, atendendo aos interesses de poderosas empreiteiras, decidiu remover as famílias que moravam na Vila Autódromo há

\footnotetext{
${ }^{29}$ Ver página: https://www.facebook.com/museudasremocoes/ (última consulta 15/11/2016).

${ }^{30}$ Ver matéria publicada no periódico Brasil de Fato: https://www.brasildefato.com.br/2016/05/18/museu-das-remocoes-expoememoria-de-resistencia-da-vila-autodromo-no-rio/ (última consulta 15/11/2016).
} 
mais de 50 anos e que estavam com sua situação fundiária regularizada.

O processo de remoção foi tenso e envolveu luta, sangue, disputa. Pelo menos 580 famílias foram removidas, mas talvez a prefeitura não contasse com a resistência de 20 famílias que insistiam em dizer: "Nem todos tem um preço" ${ }^{31}$. Essas vinte famílias com o auxílio de apoiadores e amigos ( $r$ )existiram, inventaram novas possibilidades de estar no mundo e venceram os Jogos Olímpicos ${ }^{32}$. Foi neste quadro, que, entre janeiro e fevereiro de 2016, organizou-se um grupo de quefazeres visando a criação do Museu das Remoções, a partir dos escombros das casas destruídas, dos registros documentais e das memórias da Vila Autódromo.

O Museu das Remoções, criado por uma comunidade popular que enfrentou o poder destruidor do poder público e descobriu na luta o seu próprio poder, chamou para si a tarefa e a responsabilidade de contar a história das remoções a partir da perspectiva dos afetados pelas políticas de remoções. O lema do Museu: "Memória não se remove", passou a ser a chave de todas as ações, projetos e encaminhamentos. É claro que essa afirmação implica um desejo, um desafio, um sinal e uma disposição para a luta.

O lançamento do Museu, ocorrido no dia 18 de maio de 2016, contou com a construção de 7 (sete) esculturas realizadas por estudantes de arquitetura da Universidade Anhanguera ${ }^{33}$, a partir dos escombros das casas destruídas. O Museu das Remoções apresentou uma potente crítica no que se refere ao tema, aparentemente pacificado: "Museus e Paisagens Culturais" e indicou que os principais destruidores da paisagem cultural são o

\footnotetext{
${ }^{31}$ Está frase foi grafitada na fachada de muitas casas na Vila Autódromo.

32 Ver a matéria publicada no periódico "El País": http://brasil.elpais.com/brasil/2016/07/25/politica/1469450857 996933.html ${ }^{33}$ O projeto das esculturas foi coordenado pela arquiteta e professora Diana Bogado.
} 
poder público em articulação com o grande capital, as grandes corporações e as grandes empreiteiras. Durante as Olimpíadas o Museu teve um papel muito forte e expressivo e atraiu especialmente o público internacional. Ao longo de todo o ano de 2016, o Museu das Remoções realizou e participou de ações na Vila Autódromo e em vários lugares da cidade do Rio de Janeiro.

Em maio de 2017 o Museu das Remoções comemorou o seu primeiro aniversário com a doação ao Museu Histórico Nacional de escombros de diversas casas da Vila Autódromo. E em maio de 2018 programou no Museu da República a realização de exposições, debates e filmes tratando do tema das remoções.

\section{Considerações finais}

Nas últimas três décadas foi possível observar a disputa de diferentes grupos em torno do social da museologia. Quais foram os precursores dos trabalhos museológicos de cariz social no Brasil, em Portugal e por todo o mundo? Quem contribuiu para a valorização das relações sociais, das ações e manifestações socioculturais como temas de interesse e estudo da museologia? Haverá um locus museal ${ }^{34}$ específico para a museologia social? A quem pertence o social da museologia? Qual o lugar das comunidades populares, dos movimentos sociais, dos direitos humanos e da cidadania na museologia? Estes questionamentos continuam animando debates.

No entendimento dos autores deste artigo, estas questões e disputas apontam para a tomada de consciência por parte de profissionais dos museus e da museologia em relação à museologia social, nas suas dimensões teórica, prática e crítica; bem como, para o reconhecimento dos trabalhos contemporâneos que valorizam o bem social e a socialização das

\footnotetext{
${ }^{34}$ Compreende-se como locus museal a constituição de lugares sociais, culturais, políticos e econômicos diferenciados que se ancoram em perspectivas museológicas específicas e singulares.
} 
ações humanas. Este processo de empoderamento reverbera e transborda, especialmente quando entra em sintonia com movimentos sociais abrangentes como o Fórum Social Mundial. Neste sentido, é estimulante compreender a museologia social como uma ferramenta de trabalho colocada a favor da cidadania, dos direitos humanos, dos direitos dos trabalhadores, dos direitos à terra e à moradia, dos direitos das mulheres, dos direitos dos povos indígenas e dos negros, dos direitos da comunidade $\mathrm{LGBT}^{35}$ e outros direitos.

A partir do final da década de 1960, foram os modos de fazer e saber, além dos edifícios, obras de arte e artefatos raros, que se tornaram objetos de interesse museológico. Neste quadro, a nova museologia, do ponto de vista teórico, prático e crítico, não se dirigiu exclusivamente aos artefatos; a sua atenção incidiu também sobre os mentefatos, os biofatos e os sujeitos sociais. Assim, no contexto das últimas décadas do século XX o museu foise transformando num centro de expressão da vida social de grupos que trabalhavam a partir da memória, do patrimônio e das referências culturais.

Ducan Cameron (1971) em ensaio famoso, descreveu e analisou comparativamente duas tendências: o museu como "templo das musas" e o museu como "fórum de ideias". Nesse artigo, Cameron questionava a crise de identidade dos museus e salientava que grande parte deles se esforçavam para manter uma identidade como "templos das musas", com foco na coleta, preservação, interpretação e exposição de artefatos, enquanto os novos museus afastavam-se da ênfase nos objetos e buscavam tornar-se "fórum de ideias e fóruns de debates públicos" em torno de questões sociais, políticas e culturais relevantes para a sociedade.

\footnotetext{
${ }^{35}$ Sabemos que esta sigla está em ebulição. Neste artigo resolvemos nos ater àquela que no Brasil ficou clássica em termos de política pública.
} 
Existe uma relação muito forte entre a museologia social e a "Educação como prática da liberdade" especialmente quando apontam para a necessidade de transformações políticas, sociais e econômicas. Seguindo por este caminho muitos museus foram se aproximando da ideia de museu fórum, de sítios de encontros, diálogos, debates e ações comprometidos com uma perspectiva libertária de memória, património e ação cultural.

Ao longo dos últimos quarenta anos a ideia de museu passou por transformações bastantes radicais. De casas que guardam e acumulam acervos e coleções, os museus passaram a ser centros de convivência e de expressão da vida social das comunidades; espaços de construção social de memórias e processos de identificação. Ao longo desse tempo, os museólogos também se redefiniram, para além de profissionais de museus e guardiões de tesouros eles assumiram-se como mediadores, educadores, pesquisadores, trabalhadores sociais, cientistas sociais e militantes de movimentos sociais. Todo esse conjunto de novas ideias contribuiu para que o social no âmbito dos museus se transformasse em tema contemporâneo, contribuindo para o surgimento de novas tipologias de museus, de carácter dialógico, democrático, participativo e inclusivo.

A nova museologia convocava os sujeitos sociais a intervir ativamente e a resistir aos determinismos da História dos heróis e do passado glorioso. O caráter militante dessa ação museológica assentava-se na diferença fundamental entre a memória como lar da tradição e a memória como potência e ferramenta para a transformação social.

Neste contexto, qualquer referência às transformações ocorridas na museologia ao longo da segunda metade do século $\mathrm{XX}$, implica assumir o lugar e o papel de destaque ocupado pelos Ecomuseus e Museus de Comunidade, pois, um pouco por todo o mundo, estas experiências museais passaram a ocupar um lugar central e inovador. A par destas experiências surgiram ao longo das últimas décadas do século $X X$ e início do século $X X I$, os 
museus locais em Portugal e um pouco por toda a América Latina os museus comunitários, os museus indígenas, os museus quilombolas, os museus de favela, os museus de percurso e de território, os pontos de memória e pontos de cultura e ainda os museus de memórias e de resistência. Muitos desses museus nasceram como resposta às necessidades de grupos sociais específicos proteger e divulgar memórias, patrimónios e expressões culturais; mas nasceram também da compreensão sagaz de que é possível utilizar os museus, sem nenhum pudor, à semelhança do que sempre foi feito pelos grupos sociais dominadores, a favor de determinados projetos, de lutas bem específicas. Boa parte desses museus desconhece as teorias e práticas museológicas convencionais, bem como a cadeia operacional dos museus e, no entanto, desenvolvem trabalhos importantes na proteção e divulgação de seus patrimónios e memórias.

No campo sociomuseal a memória é utilizada numa perspectiva de transformação da vida presente. Pesquisas e exposições são realizadas com objetivo de conhecer o patrimônio e as manifestações culturais em movimento na vida social contemporânea.

Brasil e Portugal são países em que a museologia social ou sociomuseologia ganhou densidade. A coexistência de formações universitárias em museologia no âmbito da graduação e da pósgraduação, as desigualdades sociais a par das desigualdades na seleção dos patrimônios a serem musealizados pelo Estado, a compreensão do museu como prática social e ferramenta de luta e o crescente ativismo social de indivíduos e grupos imbricados com iniciativas museológicas transformadoras são elementos que permitiram a assunção da sociomuseologia de forma alargada e militante.

Em 2007, no âmbito do XII Atelier Internacional do MINOM, Mário Moutinho, propôs a Definição Evolutiva da Sociomuseologia, numa clara alusão à Definição Evolutiva de 
Ecomuseu de G. H. Rivière. Segundo o referido autor: " $A$ Sociomuseologia traduz uma parte considerável do esforço de adequação das estruturas museológicas aos condicionalismos da sociedade contemporânea. A abertura do museu ao meio e a sua relação orgânica com o contexto social que lhe dá vida, têm provocado a necessidade de elaborar e esclarecer relações, noções e conceitos que podem dar conta deste processo. A Sociomuseologia constitui-se assim como uma área disciplinar de ensino, investigação e atuação que privilegia a articulação da Museologia em particular com as áreas do conhecimento das Ciências Humanas, dos Estudos do Desenvolvimento, da Ciência de Serviços e do Planeamento do Território. A abordagem multidisciplinar da Sociomuseologia visa consolidar $o$ reconhecimento da Museologia como recurso para o desenvolvimento sustentável da humanidade, assente na igualdade de oportunidades e na inclusão social e económica. A Sociomuseologia assenta a sua intervenção social no património cultural e natural, tangível e intangível da humanidade. O que caracteriza a Sociomuseologia não é propriamente a natureza dos seus pressupostos e dos seus objetivos, como acontece em outras áreas do conhecimento, mas a interdisciplinaridade com que apela a áreas do conhecimento perfeitamente consolidadas e as relaciona com a Museologia propriamente dita." (Moutinho, 2007, Lisboa)

No contexto mais amplo dos processos contemporâneos de globalização econômica e cultural a sociomuseologia confrontase com as questões de hibridação cultural e novas lógicas do que hoje podemos entender como comunidades e novas territorialidades.

As noções de cultura, patrimônio, memória, comunidade, educação, participação, diferença, processo museal, diversidade e territorialidade, tão caras à sociomuseologia, precisam ser (re)desenhadas e (re)contextualizadas à luz de uma perspectiva crítica para que se possa enfrentar problemas contemporâneos 
que passam pelos processos de urbanização e gentrificação, de mercantilização cultural e de transnacionalização de bens culturais; pelas questões produzidas pelos movimentos emigratórios, pelos refugiados e suas memórias e patrimônios; pelos problemas gerados com megaeventos e também com grandes investimentos em megamuseus, frente ao desprezo e ao desrespeito em relação à manutenção da dignidade da vida humana e pelos enfrentamentos cada vez mais recorrentes entre os defensores de um paradigma político laico-humanista e os defensores de um paradigma político religioso, teocrático e monoteísta.

$\mathrm{O}$ artigo que aqui se oferece tem, pelo menos, dois objetivos singelos: 1. Estimular o debate levando em conta algumas questões aqui apresentadas; 2 . Contribuir para a inspiração e a identificação de temas de pesquisa e ação. Caso um destes objetivos seja alcançado os autores sentem-se contemplados.

\section{Autores}

\section{Mario Chagas}

Poeta. Graduação em Museologia pela Universidade Federal do Estado do Rio de Janeiro (Unirio - 1976), licenciatura em Ciências pela Universidade do Estado do Rio de Janeiro (Uerj - 1980), mestrado em Memória Social pela Unirio (1997) e doutorado em Ciências Sociais pela Uerj (2003). Um dos responsáveis pela Política Nacional de Museus (lançada em 2003) e um dos criadores do Sistema Brasileiro de Museus (SBM), do Cadastro Nacional de Museus (CNM), do Programa Pontos de Memória, do Programa Nacional de Educação Museal (Pnem) e do Instituto Brasileiro de Museus (Ibram). Fundador da Revista Brasileira de Museus e Museologia - MUSAS e criador do Programa Editorial do Ibram. Diretor do Museu da Republica, professor da Unirio, com atuação na Escola de Museologia e no Programa de Pós-graduação em Museologia e Patrimônio (Ppgpmus); professor visitante da Universidade Lusófona de Humanidades e Tecnologias (ULHT), professor colaborador do Programa de Pósgraduação de Museologia da Universidade Federal da Bahia (Ufba). Tem experiência nacional e internacional no campo da museologia e da museografia, com ênfase na museologia social, nos museus sociais e comunitários, na educação museal e nas práticas sociais de memória, política cultural e patrimônio 


\section{Judite Primo}

Diretora do Departamento em Museologia da Universidade Lusófona de Humanidades e Tecnologias de Lisboa. Diretora do Doutoramento e do Mestrado em Museologia na ULHT. Professora titular da Cátedra UNESCO WINTWIN "Educação, cidadania e diversidade cultural" (no.2017) Docente das disciplinas: Museologia e Património, Museologia e Pensamento Contemporâneo, Introdução ao Pensamento Contemporâneo, Museologia e Políticas Culturais e Museologia e Género na ULHT Membro do Conselho editorial da revista Cadernos de Sociomuseologia. Tem experiência na área de Museologia, com ênfase em Sociomuseologia, atuando principalmente nos seguintes temas: museologia, Sociomuseologia, Património, Museus Locais e Memória Social. Doutorada em Educação pela Universidade Portucalense Infante D. Henrique (2007), Mestre em Museologia pela Universidade Lusófona de Humanidades e Tecnologias (2000) possui graduação em Museologia pela Universidade Federal da Bahia (1996).

\section{Paula Assunção}

Museóloga e pesquisadora. Presidenta do Movimento Internacional para uma Nova Museologia no período de 2011 a 2016. Membro da diretoria do ICOM/ICTOP. Professora de Teoria do Patrimônio e de Sociomuseologia na Reinwardt Academy, em Amsterdã, Holanda. Tem escrito, organizado e participado de diversas publicações no campo da sociomuseologia.

\section{Claudia Storino}

Mestre em Memória Social (Unirio, 2008), especialista em Preservação e Restauração de Monumentos e Conjuntos Históricos (CECRE - UFBA / IPHAN / UNESCO, 1990), arquiteta (Universidade Santa Úrsula,1985), designer (PUC-RJ, 1980). Tradutora-Intérprete (Português/Inglês) pela Escola Americana do Rio de Janeiro. Faz parte do quadro técnico do IPHAN desde 1984. No período de 2004 a 2009 chefiou o Núcleo de Arquitetura e foi Coordenadora Técnica Substituta do Departamento de Museus e Centros Culturais do IPHAN; no período de 2009 a 2012 foi Coordenadora de Espaços Museais, Arquitetura e Expografia do Instituto Brasileiro de Museus (IBRAM) e membro do Conselho Consultivo do Patrimônio Cultural (IPHAN/MinC); de julho de 2012 à atualidade dirige o Centro Cultural Sítio Roberto Burle Marx, Unidade Especial do IPHAN. 
